Research Article

www.ijrap.net

\title{
IMPACT OF MICRONUTRIENT FORTIFIED FOOD SUPPLEMENT ON NUTRITIONAL PROFILE AMONG GINNING WOMEN WORKERS
}

D.Sridevi ${ }^{1 *}$ and S.Radhaisri ${ }^{2}$

${ }^{1}$ Department of Nutrition and Dietetics, Dr. NGP Arts and Science College, Coimbatore, India

${ }^{2}$ Department of Nutrition and Dietetics, PSG Arts and Science College, Coimbatore, India

Received on: 09/05/13 Revised on: 10/06/13 Accepted on: 10/07/13

\author{
*Corresponding author \\ E-mail: ss_prodn@yahoo.co.in \\ DOI: 10.7897/2277-4343.04414 \\ Published by Moksha Publishing House. Website www.mokshaph.com \\ All rights reserved.
}

\section{ABSTRACT}

Ginning factory discharges large amount of cotton dust, which might decrease haematological indices among the selected subjects. An attempt was made to study the haematological indices of women labourers located in the urban areas of Tirupur and Erode Districts of Tamil Nadu, India. Totally 150 non-pregnant, non-lactating adult women performing varied textile tasks and aged between 20 to 60 years were identified randomly from ginning $(\mathrm{n}=150)$ (gin house, gutter and sorting sections) industries. Socio demographic, work pattern, nutritional and health status were assessed by administering a questionnaire. Further, to correct micronutrient deficiency, iron and folic acid fortified soy biscuits were formulated. Intervention study was conducted among the selected moderate anaemic ginners $(\mathrm{n}=20) .100 \mathrm{~g}$ of micronutrient fortified soy biscuit containing $13.5 \mathrm{~g}$ of protein, $8.4 \mathrm{mg}$ of iron (ferrous fumarate) and $120 \mu \mathrm{g}$ of folic acid was supplemented to experimental group of women as a midmorning and midevening snack for a period of four months. Therapeutic efficacy of food supplement was studied by assessing their anthropometric and haematological conditions at pre and post supplementation period. Anthropometric indices showed an improvement in weight $(48.7 \pm 4.98$ to $51.5 \pm 6.25)$ and BMI (19.02 to 23.04). Haematological indices revealed that the mean haemoglobin of experimental group improved to $11.04 \pm 0.56 \mathrm{~g} / \mathrm{dl}$ from $9.1 \pm 0.67$. Similarly increase in serum iron from $61.9 \pm 3.24$ to $65.0 \pm 2.95 \mu \mathrm{g} / \mathrm{dl}$ was noticed and showed a significant difference at 1 per cent. Improvement in total protein $(6.62 \pm 0.49$ to $8.11 \pm 0.20 \mathrm{~g} / \mathrm{dl})$, albumin $(3.9 \pm 0.36$ to $4.73 \pm 0.31 \mathrm{~g} / \mathrm{dl})$ and globulin $(2.82 \pm 0.24$ to $3.8 \pm 0.29 \mathrm{~g} / \mathrm{dl})$ showed significant difference at 1 per cent level. Similarly, an increase in Total WBC count (7326 \pm 19.5 to $9725 \pm 25.5$ cumm), reduction in lymphocyte ( $942.16 \pm 3.6$ to $35.2 \pm 2.2$ per cent) seen among the ginning women workers.

Keywords: Ginning workers, micronutrient, fortified, ferrous fumarate, folic acid

\section{INTRODUCTION}

Occupational health is branch of community medicine which deals with the effect of occupation of work place on human health ${ }^{1}$. Every occupation is associated with one or other ill effects on health. One such occupational group is cotton textile workers. Ginning factory includes the sorting house, gin house and gutter section. Sorting involves the sorting of cotton according to quality. The seeds are separated from cotton in the gin house and collected in gutter ${ }^{2}$. Ginning factory discharge large amount of cotton dust and inhalation of dust is an important cause of interstitial lung disease, anaemia and other health related problems which are susceptible to various morbid conditions which may range from chronic respiratory disease. Today is an era of women who have diverse role to play in society; often they handle two or more tasks simultaneously. Therefore they are prone to suffer from work-related diseases, which are further complicated by social, psychological and physiological issues. Roughly, 1 out of 300 female is suffering from some occupation related disease. The working condition of women in India is currently similar to those found in early $19^{\text {th }}$ centuries in industrial countries ${ }^{3}$. Ginning is one of the unorganized occupations of textile industries, which employ more number of women and are exposed to physical stress and chemical toxicants leading to health problem which are further aggravated cause of malnutrition and anemia. Anaemia and even more mild levels of iron deficiency impair immune function and were associated with reduced work output among women cotton mill workers. The effect of iron supplementation (ferrous fumarate) on the iron status and physical work capacity was studied in anaemic middle class women. It was observed that 60 per cent of the subjects were suffering from mild to moderate iron deficiency anaemia ${ }^{4}$. Ergonomic studies in industrial workers were many, but there were limited ergonomic studies in the ginning section of textile women workers. Therefore, it was considered appropriate to take up the issues of ergonomic study of work pattern, nutritional and health status of textile women workers and with special emphasis on correcting their micronutrient deficiency through intervention programme.

\section{MATERIALS AND METHODS}

A ginning factory located at Erode and Tirupur were chosen for the study. 150 non pregnant and non lactating women performing varied textile tasks and aged between 20-60 years were identified randomly from ginning industries. Women working in different sections of ginning factory (Srimurugan, Sudha, Venkateshwara and Bagyammal factories) namely, ginhouse, gutter and sorting were covered for the study. Interiew technique was used to collect information regarding anthropometric characteristics like height, weight and Body Mass Index. Hematological indices such as blood haemoglobin, serum iron, serum albumin, globulin and total protein, WBC count and differential count were estimated at the beginning and at the end of the intervention period for the selected groups of women. The study was carried out as 
per Ethical guidelines and informed consent was taken from the participants.

\section{Conduct of Intervention Study}

Hemoglobin estimation was carried out for all the 150 selected textile women workers. The prevalence picture showed moderate degree of anaemia ranged between 7 to $9.9 \mathrm{~g} / \mathrm{dl}$ among the selected women with the mean haemoglobin level of $(7.89 \pm 0.19 \mathrm{~g} / \mathrm{dl})$. This was supported by the studies of Raffle $(2005)^{5}$ and Saadia (2006) ${ }^{6}$ who mentioned that cotton ginners are exposed to cotton dust quite frequently and they have high prevalence of respiratory symptoms, morbid pattern, clinical deficiency for anaemia and poor health status. Considering these, for further study, women working in ginning units were selected for intervention programme. Based on their haemoglobin values and willingness to participate in the food supplementation study, women who were classified under moderate anaemia category having haemoglobin level between 7 to $9.9 \mathrm{~g} / \mathrm{dl}$ were included. Totally 40 moderately anaemic women with 8-9 $\mathrm{g}$ per $\mathrm{dl}$ of haemoglobin were divided into control $(\mathrm{n}=20)$

Table 1: Hemoglobin level of the selected textile women workers (N=150)

\begin{tabular}{|c|c|c|c|c|}
\hline \multirow{2}{*}{$\begin{array}{c}\text { Hb Grades } \\
\text { g/dl }\end{array}$} & \multicolumn{4}{|c|}{ Ginning (150) } \\
\cline { 2 - 5 } & Gin house & Gutter & Sorting & Total \\
\cline { 2 - 5 } & $\mathrm{n}(\%)$ & $\mathrm{n}(\%)$ & $\mathrm{n}(\%)$ & $\mathrm{n}(\%)$ \\
\hline Normal- $12-14$ & $11(13.7)$ & $7(16)$ & $5(20)$ & $23(15.3)$ \\
\hline Mild- $10<12$ & $19(24)$ & $12(27)$ & $8(32)$ & $39(26)$ \\
\hline Moderate- $7<10$ & $44(55)$ & $26(57)$ & $10(40)$ & $80(53.3)$ \\
\hline Severe $<7$ & $6(7.5)$ & - & $2(8)$ & $8(5.4)$ \\
\hline
\end{tabular}

and experimental $(n=20)$ groups of women. Based on acceptability trails, nutrient contribution and feasibility for feeding, $100 \mathrm{~g}$ of micronutrient fortified soy biscuit containing $13.5 \mathrm{~g}$ of protein, $8.4 \mathrm{mg}$ of iron (ferrous fumarate) and $120 \mu \mathrm{g}$ of folic acid was supplemented to experimental group of women as a midmorning and midevening snack for a period of four months was chosen, because only minimum dosage of iron (ACC/SCN new 1990) was considered in this study as the selected sample of women for intervention were moderately anaemic. They were monitored and consumption of biscuit by the members was ensured throughout the supplementation study. Control of hook worms is significant strategy for reducing anaemia. Hence before starting the intervention, the selected groups of women were given deworming tablets (Albendozole 400 $\mathrm{mg}$ ) twice (once in 15 days). Impact of the micronutrient fortified soy biscuits on moderate anaemic women were assessed through their anthropometric measurements and haematological picture such as blood hemoglobin serum iron, protein, albumin, globulin and WBC differential count.

Table 2: Anthropometric measurement of the selected ginning women workers $(\mathrm{N}=40)$

\begin{tabular}{|c|c|c|c|}
\hline \multirow{2}{*}{ Criteria } & \multicolumn{3}{|c|}{ Anthropometric Measurement } \\
\cline { 2 - 4 } & Height (Cm) & Weight (Kg) & BMI \\
\cline { 2 - 4 } & ICMR 151 & 50 & 22 \\
\hline $\begin{array}{c}\text { Control } \\
\text { Initial }\end{array}$ & $159.1 \pm 6.33$ & $55.5 \pm 6.07$ & 21.68 \\
\hline Final & $159.1 \pm 6.33$ & $53.85 \pm 5.95$ & 20.62 \\
\hline T. Value & - & $2.7^{*}$ & $1.06^{*}$ \\
\hline $\begin{array}{c}\text { Experimental } \\
\text { Initial }\end{array}$ & $156.8 \pm 6.33$ & $48.7 \pm 4.98$ & 19.02 \\
\hline Final & $156.8 \pm 6.33$ & $51.5 \pm 6.25$ & 23.04 \\
\hline T. Value & - & $5.34^{* *}$ & $5.62^{* *}$ \\
\hline
\end{tabular}

** Significant at 1 per cent level * Non Significant

Table 3: Mean protein, albumin and globulin of the selected ginning workers $(N=40)$

\begin{tabular}{|c|c|c|c|c|c|c|c|c|c|}
\hline \multirow[t]{2}{*}{ Criteria } & \multirow{2}{*}{$\begin{array}{c}\# \\
\text { Normal } \\
\text { value }\end{array}$} & \multicolumn{3}{|c|}{ Control } & \multicolumn{3}{|c|}{ Experimental } & \multirow{2}{*}{$\begin{array}{l}C_{f} \\
V_{s} \\
\mathbf{E}_{\mathrm{f}}\end{array}$} & \multirow{2}{*}{$\begin{array}{l}C_{\text {f }} \\
V_{s} \\
E_{f}\end{array}$} \\
\hline & & Initial & Final & T value & Initial & Final & T value & & \\
\hline $\begin{array}{l}\text { Total Protein } \\
(\mathrm{g} / \mathrm{dl})\end{array}$ & 6.83 & $6.15 \pm 0.40$ & $6.22 \pm 0.39$ & $3.30 *$ & $\begin{array}{c}6.62 \pm \\
0.49 \\
\end{array}$ & $\begin{array}{c}8.11 \pm \\
0.20 \\
\end{array}$ & $10.87 * *$ & $2.13^{\mathrm{ns}}$ & $12.9 * *$ \\
\hline $\begin{array}{l}\text { Albumin } \\
(\mathrm{g} / \mathrm{dl})\end{array}$ & $\begin{array}{l}3.8 \\
5.6\end{array}$ & $3.46 \pm 0.40$ & $3.46 \pm 0.36$ & $2.35 *$ & $3.9 \pm 0.36$ & $4.73 \pm 0.31$ & $3.89 * *$ & $1.02^{\mathrm{ns}}$ & $3.62 * *$ \\
\hline $\begin{array}{l}\text { Globulin } \\
(\mathrm{g} / \mathrm{dl})\end{array}$ & $2.3-3.5$ & $2.72 \pm 0.33$ & $2.76 \pm 0.28$ & $2.47 *$ & $2.82 \pm 0.24$ & $3.28 \pm 0.24$ & $6.16^{* *}$ & $2.15^{\mathrm{ns}}$ & $8.57 * *$ \\
\hline
\end{tabular}

${ }^{\text {ns }}$-non significant * Significant at 5 per cent level ** Significant at 1 per cent level \# Kanai.L Mukharjee (2001), Vol (1) $\mathrm{C}_{1-C}$ ControlInitial,

$\mathrm{E}_{1}$-Experimental Initial, $\mathrm{C}_{\mathrm{f}}$-Control Final, $\mathrm{E}_{\mathrm{f}}$-Experimental Final

Table 4: Total differential and WBC count of the selected ginning workers $(\mathrm{N}=40)$

\begin{tabular}{|c|c|c|c|c|c|c|c|c|c|}
\hline \multirow[t]{2}{*}{ Criteria } & \multirow{2}{*}{$\begin{array}{c}\# \\
\text { Normal } \\
\text { Value }\end{array}$} & \multicolumn{3}{|c|}{ Control } & \multicolumn{3}{|c|}{ Experimental } & \multirow{2}{*}{$\begin{array}{l}\mathbf{C}_{\mathrm{f}} \\
\mathbf{V}_{\mathrm{s}} \\
\mathbf{E}_{\mathrm{f}}\end{array}$} & \multirow{2}{*}{$\begin{array}{l}\mathbf{C}_{\mathrm{f}} \\
\mathbf{V}_{\mathrm{s}} \\
\mathbf{E}_{\mathrm{f}}\end{array}$} \\
\hline & & Initial & Final & T Value & Initial & Final & T Value & & \\
\hline WBC Count Cumm & $4000-11500$ & $6562 \pm 12.3$ & $7020 \pm 2.9$ & $2.97 *$ & $7326 \pm 19.5$ & $9725 \pm 25.5$ & $6.27 * *$ & $2.57 *$ & $8.27 * *$ \\
\hline Neutrophlis s \% & $40-75$ & $73.5 \pm 0.42$ & $71.5 \pm 0.45$ & $2.22 *$ & $69.21 \pm 7.3$ & $54.31 \pm 6.2$ & $5.13 * *$ & $2.02^{\mathrm{ns}}$ & $6.25 * *$ \\
\hline Lymphocyte \% & $20-45$ & $44.6 \pm 0.7$ & $43.06 \pm 0.29$ & $2.01^{\mathrm{ns}}$ & $42.16 \pm 3.6$ & $35.2 \pm 2.2$ & $3.45 * *$ & $1.57^{\mathrm{ns}}$ & $4.97 * *$ \\
\hline Eosinophils \% & $1-6$ & $9.7 \pm 0.34$ & $9.7 \pm 0.34$ & $2.24^{\mathrm{ns}}$ & $7.4 \pm 0.8$ & $4.3 \pm 0.59$ & $3.57 * *$ & $2.10^{\mathrm{ns}}$ & $3.59 * *$ \\
\hline Monocyte $\%$ & $1-10$ & $11.6 \pm 0.53$ & $11.4 \pm 0.52$ & $2.22^{\mathrm{ns}}$ & $11.6 \pm 0.5$ & $9.5 \pm 0.2$ & $3.32 * *$ & $1.99^{\mathrm{ns}}$ & $4.01 * *$ \\
\hline
\end{tabular}

${ }^{n s}$-non significant * Significant at 1 per cent level ** Significant at 1 per cent level \# Kanai.L Mukharjee(2001), Vol(1) $\mathrm{C}_{1-C}$ ControlInitial,

$\mathrm{E}_{1}$-ExperimentalInitial, $\mathrm{C}_{\mathrm{f}}$-ControlFnal, $\mathrm{E}_{\mathrm{f}}$-Experimental Final 
RESULTS AND DISCUSSION

Prevalence of Anemia among the Selected Textile Ginning Women Workers

Hemoglobin the most extensively used parameter is reflection of end stage of iron deficiency. The hemoglobin level of women working in different categories and degree of anaemia were recorded and presented in Table 1. Women working in ginning mills were suffering from severe degree of anemia (5.4 per cent). Normal level of haemoglobin (12-14 g/dl) was found among 15.3 per cent of women. About 26 per cent of women working in ginning industries showed mild degree anemia where as 53.3 per cent had moderate degree of anaemia. It is observed that higher percentage of ginners were with moderate degree of anaemia. It is accordance with the study of (fotedar 2005) ${ }^{7}$ who identified that 66 per cent of women working in ginning mill suffered from moderate degree of anemia

\section{Changes in Anthropometric Measurement}

Physical work capacity of the selected women working in ginning mills was assessed by observing changes in anthropometric measurements before and after micronutrients supplementation. Anthropometric measurement (height and weight) were recorded before and after intervention and respective BMI was computed and the mean values are presented in Table 2 . The mean height of the control and experimental groups of women was 159.1 and $156.8 \mathrm{~cm}$ respectively and no change was observed after intervention period since they come under adult group. The mean weight ranged between 55.5 and $48.7 \mathrm{~kg}$ in the selected population before intervention however, gain in the body weight was recorded in the experimental group with a mean increase of $4 \mathrm{~kg}$ after intervention. Increase in body weight of the food supplemented group was significantly higher than the initial valve $(\mathrm{p}<0.01)$. This weight increment in food supplemented group could be due to the additional calories $(482 \mathrm{k} . c a l)$ provided through the micronutrient rich food. Consequently, there was increase in the BMI of experimental groups of women which was statistically significant $(\mathrm{P}<0.01)$ at one per cent level. It is clear that the experimented group had BMI value of 19.02 before supplementation due to poor food intake and increased physical work. However, on supplementation with micronutrient fortified soy biscuits it increased to 23.04. Considering the control group, there was no significant changes in anthropometric measurements confirming the significant role of food supplementation in improving weight increment in experimental group of women.

\section{Serum Protein}

Total Protein, albumin and globulin levels of the selected women working in ginning mills were analysed before and after supplementation and the mean values are presented in Table 3. The mean total protein level in both the groups was relatively less and closer to lower values of normal range as $6.15 \mathrm{~g} / \mathrm{dl}$ and $6.22 \mathrm{~g} / \mathrm{dl}$ in the control and experimental groups respectively. However, on supplementation considerable increase in total protein was observed in the experimental group from $6.62 \mathrm{~g} / \mathrm{dl}$ and $8.11 \mathrm{~g} / \mathrm{dl}$ showed a significant difference at 1 per cent level. Similar, observations were noticed in the albumin and globulin levels. The mean serum albumin level was $3.43 \mathrm{~g} / \mathrm{dl}$ and $3.46 \mathrm{~g} / \mathrm{dl}$ in the control and experimental group of women initially which was changed to $3.9 \mathrm{~g} / \mathrm{dl}$ and $4.73 \mathrm{~g} / \mathrm{dl}$ respectively finally showing a significant difference only in the values of experimental group of women. The mean globulin level recorded before supplementation was $2.72 \mathrm{~g} / \mathrm{dl}$ and $2.76 \mathrm{~g} / \mathrm{dl}$ in the control and experimental groups respectively which increased to $2.82 \mathrm{~g} / \mathrm{dl}$ and $3.28 \mathrm{~g} / \mathrm{dl}$ respectively. A Considerable and significant improvement was observed only in the experimental group of women attributed to food supplementation.

\section{Total Differential and WBC Count}

The mean total WBC count differential WBC count (Neutrophils, Lymphocyte, Eosinophils) before and after supplementation is presented in Table 4 . The differential WBC count was increased with respect to polymorphs, lymphocyte and eosinophils in the subjects before supplementation due to increased rate of infections ${ }^{8}$. The endotoxins, heat stable lipopolysaccharide protein complex contained in the cell wall of gram -ve bacteria are responsible for the respiratory diseases of cotton textile workers9. Mean WBC count, was found to be within the normal range of $4000-11,500$ per cumm in both control and experimental group of women ginning workers. Chatterje $(1998)^{10}$ stated that in infectious condition, the neutrophil leucocytes manufacture a trypsin like enzyme to digest bacteria and dead tissue. The table also shows that mean lymphocyte count decreased from 42.16 to 35.2 after supplementation. However on supplementation of micronutrient fortified soy biscuit increased the immune status helped to reduce the eosinophil count to 4.3 among experimental group of women workers. Mean monocyte level lowered from 11.6 to 9.5 on supplementation. Statistical analysis showed that there was a significant difference at 1 per cent level in WBC and differential WBC count on supplementation. It is concluded from the study that women working in textile industries were suffering from moderate degree of anemia. Provision of micronutrient food supplement showed an appreciable change in haematological conditions. Hence, the working women were found at risk of developing health as well as nutritional problems. Therefore there is a need for specific nutritional and health programme to be initiated by government health care system to create awareness among working women in textile industries. Provision of periodical health surveillance, proper medical treatment to affected women and facilitating proper physical arrangement such as dust control measures lighting, availability of water and fresh air at work place minimize the health problems to certain extent.

\section{REFERENCES}

1. Park. Text Book of Preventive and Social Medicine $15^{\text {th }}$ ed. Jabalpur: BanarsidasBhanot publishers; 2005. p. 542-56.

2. Jannet JV and Jeyanthi GP. Pulmonary Health Status of Ginning Factory Women laborers in Triupur. Indian Journal of occupation and environmental medicine 2006; 10(3): 116.

3. Mohamed, Mahmoud S Abd El Me geed and Saws Mohamed et al. A Study of Occupational Health Hazards among Spinning Factory Workers. Ass Univ. Bult Environ 2004; 7(1): 25. 
4. Busta. Iron Deficiency Anemia and the Health Status of Female Textile Workers in Indonesia. Am., clin. Nutrition 2005; 1(6): 3291.

5. Raffle Hunters disease of occupations, $6^{\text {th }}$ ed. London, Hodder and Stoughton; 2005. p. 690-705.

6. Saadia Prevalence of Byssinosis in Textile Mills at Ahmedabad. India British Journal of Industrial Medicine 2006; 46(7): 87-90.

7. Fotedar. Occupational Morbidities and their Association with Nutritional and Environmental Factors among Textile Workers of Desert area of Rajasthan. Journal of Occupational Health 2005; 47 : 371-377. http://dx.doi.org/10.1539/joh.47.371 PMid:16230829

8. Swaminathan M. Advanced text book of food and nutrition, Orient Paperbacks, a division of Vision Book Pvt. Ltd., New Delhi; 1995. p. $336-368$
9. Hend Bactericidal Treatment of Raw Cotton as the Method of Business is Prevention. Allt A Journal 2003; 64(1): 88-95.

10. Chaterjee CN. Human physiology $2^{\text {nd }}$ ed. Medical allied Agency, Calcutta, India; 1998. p. 145-147.

\section{Cite this article as:}

D.Sridevi and S.Radhaisri. Impact of micronutrient fortified food supplement on nutritional profile among ginning women workers. Int. J. Res. Ayurveda Pharm. 2013;4(4):526-529 http://dx.doi.org/10.7897/ 2277-4343.04414

Source of support: Nil, Conflict of interest: None Declared 